

\section{Sumário}

I. CRônicas

A Favor de uma Corte Latino-Americana de Justiça ..................................................... 3 Nitish Monebhurrun

Sobre A SOluÇão JUdicial de CONTROvérsias Na AMÉRICA LATINA 7 Lucas Carlos Lima

A Favor de uma Corte Latino-Americana de Justiça - Uma Reação sobre a Legalidade e A Legitimidade De Seu Desenho Institucional............................................................15

Arthur Roberto Capella Giannattasio

O Estudo do Direito Internacional sob uma Nova Perspectiva: Nossa Experiência na Philip C. Jessup International Moot Court Competition............................................20 Ana Vitória Muniz Bokos, Igor Medeiros Maia, Jefferson Seidy Sonobe Hable, Gabriel de Oliveira Borba, Gilda Nogueira Paes Cambraia e Nayara Lima Rocha Da Cruz

Revisión de laudos de arbitrajes de inversión 2019: I Encuentro Anual (Santiago de

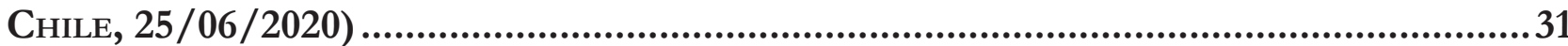
Andrés Delgado Casteleiro e Ivette Esis

II. Dossiê: Populismo e Direito Internacional / Populism and Internatio-

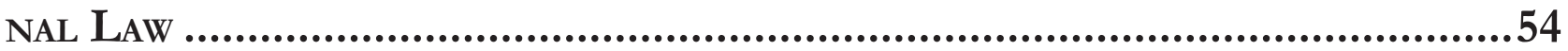

Editorial: Populism and International Law: Global South Perspectives .56 Lucas Lixinski e Fabio Morosini

Editorial: Populismo e Direito Internacional: Perspectivas do Sul Global .61 Lucas Lixinski e Fabio Morosini 
Between Science and populism: the Brazilian Response to COVID-19 from the Perspective of the legal determinants of Global Health

Deisy de Freitas Lima Ventura e Jameson Martins

Populism, ENVIronmental LAW, AND THE POST-PANDEMiC ORDER Alessandra Lehmen

Populism and the Evangelical church in Latin America: how anti-LGBTI forces TRIED TO STOP THE COLOMBIAN PEACE AGREEMENT Julia Assmann de Freitas Macedo e Fabrízio Conte Jacobucci

“Deus EM Davos": o Direito INTERnACIONAL ENTRE REACIONÁRIOS E NEOLIBERAIS NO GOVERNO BOLSONARO 121

Lucas Tasquetto e João Roriz

CHINESE POPULISM IN THE 1920s, EXTRATERRITORIALITY AND INTERNATIONAL LAW 139 Wanshu Cong

CONCEPTUALIZING UNILATERALISM, FRAGMENTATIONISM AND STATISM IN A POPULISM CONTEXT: A RISE OF POPULIST INTERNATIONAL LAW? 162 Wei Shen e Carrie Shu Shang

AUTONOMÍA ADMINISTRATIVA SIN AUTONOMÍA POLÍTICA: LA APLICACIÓN DEL MODELO "UN PAÍS dos SISTEMAs" eN HoNg Kong 186 Juan Enrique Serrano Moreno

III. Artigos sobre outros temas...................................................... 197

Um TWAiler entre nós? As contribuições de Celso Duvivier de Albuquerque Mello PARA O DIREITO INTERNACIONAL (CRÍTICO) NO BRASIL .................................................... 199

Fabio Morosini e Matheus Leichtweis

DEMOCRACIES IN DANGER: ARE JUDICIAL DIALOGUES MEANS TO REFRAIN SETBACKS IN LATIN America?.

Melina Girardi Fachin e Bruna Nowak 


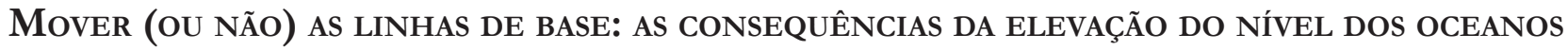
SOBRE AS ZONAS MARÍTIMAS DOS PEQUENOS ESTADOS INSULARES EM DESENVOLVIMENTO E AS ALTERNATIVAS JURÍDICAS PARA REDUZIR SEUS IMPACTOS

Alexandre Pereira da Silva

A mineração em águas profundas no Pacífico 263 Pierre-Jean Bordahandy

Dual Nationality and International Law in times of Globalization. Challenges and Opportunities for Consular Assistance and Diplomatic Protection in RECENT CASES. 288

Walter Arevalo-Ramirez e Robert Joseph Blaise Maclean

Expulsion of aliens: the application of International Law by Chilean Superior Courts 309

Regina Ingrid Díaz Tolosa

O TIPO PENAL BRASILEIRO DE PROMOÇÃo DE MIGRAÇÃO ILEGAL E O PRINCÍPIO DA NÃO CRIMINALIZAÇÃo DA MOBILIDADE HUMANA

Regina Cândido Lima e Silva Santos e Deilton Ribeiro Brasil

INDICADORES TRANSNACIONAIS DE CORRUPÇÃO AMBIENTAL: A OPACIDADE NA TRANSPARÊNCIA INTERNACIONAL

Márcio Ricardo Staffen

SubTRAÇÃo INTERNACIONAL DE CRIANÇAS: ANÁLISE DAS EXCEÇÕES AO RETORNO IMEDIATO DO MENOR À RESIDÊNCIA HABITUAL E CRÍTICA AO ENQUADRAMENTO DA VIOLÊNCIA DOMÉSTICA COMO FLEXIBILIDADE PERMISSIVA

Vivian Daniele Rocha Gabriel

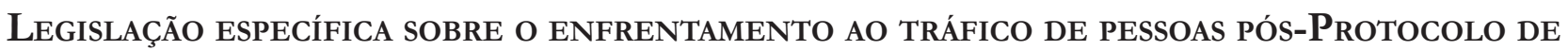
Palermo (2000): análise do Estado de Moçambique 383

Mercia Cardoso de Souza, Guirino Dinis José Nhatave e Francisco Horácio da Silva Frota 
IV. Artigos traduzidos

DIREITO INTERNACIONAL DO RECONHECIMENTO

Emmanuelle Tourme-Jouannet e Tradutor: Ademar Pozzatti Junior

V. RESENHAS

Fabio Costa Morosini, Gabriel Lee Mac Fadden Santos, Valentina Fonseca da Luz e Vinicius Tejadas Maia 


\title{
Democracies in danger: are judicial dialogues means to refrain setbacks in Latin America?*
}

\author{
Democracias em perigo: são os diálogos \\ judiciais meios para refrear retrocessos na \\ América Latina?
}

\author{
Melina Girardi Fachin** \\ Bruna Nowak***
}

\begin{abstract}
The processes of democratization in Latin America are accompanied by the rise of internationally protected human rights and their respective monitoring institutions. The Inter-American System of Human Rights is one of the central bodies in the region. In 2016 and 2017, two requests for advisory opinions regarding political trials and impeachment proceedings were presented before the Inter-American Court of Human Rights. This article aims to verify the reasons invoked by the Court to refrain itself from issuing the two advisory opinions. As of the theorizations about judicial dialogues, the study of the attributes of reciprocity and possibility of divergence points to the conclusion that the silence of the Court regarding democratic setbacks has a lot to say about the deference granted to its member States. The two refusals of requests of advisory opinions work as dialogues between the Inter-American Court and the States of the region that face democratic challenges.
\end{abstract}

Keywords: Inter-American Court of Human Rights. Advisory Opinions. Political trials. Rejections. Judicial dialogues.

* Recebido em 06/08/2019 Aprovado em 24/04/2020

** Post-Doctoral Researcher at the University of Coimbra. $\mathrm{PhD}$ and Master's Degrees in Law by the Pontifical Catholic University of São Paulo. Adjunct Professor of the Public Law Department of the Faculty of Law of the Federal University of Paraná. Coordinator of the Group of Studies on Human Rights' Systems of the Federal University of Paraná. Email: melinafachin@gmail.com

*** Master's Degree in Human Rights and Democracy by the Federal University of Paraná. Member of the Group of Studies on Human Rights' Systems of the Federal University of Paraná. Email: bruna_nowak@hotmail.com

\section{Resumo}

Os processos de democratização na América Latina são acompanhados pela ascensão dos direitos humanos internacionalmente protegidos e seus respectivos organismos de supervisão. O Sistema Interamericano de Direitos Humanos é um dos órgãos centrais da região. Em 2016 e 2017, duas solicitações de opiniões consultivas sobre juízos políticos e procedimentos de impeachment foram apresentadas perante a Corte Interamericana de Direitos Humanos. Este artigo objetiva verificar as razões invocadas pela Corte para se abster de proferir as duas opiniões consultivas. A partir das teorias sobre diálogos judiciais, o estudo dos atributos da reciprocidade e da possibilidade de dissenso aponta para a conclusão de que o silêncio da Corte a respeito de retrocessos democráticos tem muito a dizer sobre a deferência concedida a seus Estados membros. As duas rejeições de elaborar opiniões consultivas atuam como diálogos entre a Corte Interamericana e os Estados da região que enfrentam desafios democráticos. 
Palavras-chave: Corte Interamericana de Direitos Humanos. Opiniões Consultivas. Juízos Políticos. Rejeições. Diálogos judiciais.

\section{Introduction}

"Democracy is the worst form of Government except for all those other forms..."

(W. Churchill)

Democracy is always considered an inseparable element for the protection of human rights. The triad "human rights, democracy, and the rule of law" is constantly referred to as the cornerstone of the humanized and contemporary international order. This is the triad that accompanies - at least in the contemporary archetype the consolidation of the juridical conception, national and international, of the protection of human rights.

Although democracy was a concept that rested within the States' domaine réservé, it became, in the past decades, of extreme importance for the international institutions. These spheres are devoting themselves to establish international parameters of ideal democratic governments. Raising the rule of law also to the international sphere is one of the great challenges of the contemporary international order.

The Inter-American System of Human Rights is one of these spheres. Not only the political organisms of the Organization of American States are challenged by governmental changes and democratic ruptures in its members States, but the Inter-American Court of Human Rights has been invited to comment on the legality (or the lack thereof) of processes of destitution of democratically elected Presidents in some countries of the region.

More specifically, two requests for advisory opinions regarding political trials were presented before the Inter-American Court, one in 2016 and the other in 2017. The Court's reaction was to reject both of the requests. In this sense, the present article aims to study the reasons invoked by the Court to refrain itself from issuing the two advisory opinions.

The lenses of analysis are judicial dialogues. This choice was made to deepen the debate about the refusals of the Court: they do not simply represent the observance of the criteria established in previous decisions concerning advisory opinions. The subject of democracy that is behind the two requests triggers reflections about the meaning of the (apparent) silence of the Court concerning the space available for the States to decide about political judgments. This is where the theorizations about judicial dialogues play an essential role since they make clearer that the rejections also relate to a non-preponderance of the Court's words on the matter.

Conceptually, and for the expected purposes, judicial dialogues can be understood as argumentative exchanges between different legal orders. Dialogues are not restricted to cross-references but refer to mutual considerations between the interlocutors. The relations between the Inter-American Court and its member States in the scope of advisory opinions will be studied as of judicial dialogues.

Initially, the advisory jurisdiction of the Court will be detailed in order to provide an understanding of the parameters of acceptance and refusal of advisory opinions. The two requests will be contextualized in relation to the aforementioned parameters. Then, some initial thoughts about judicial dialogues will be exposed to demonstrate that dialogues work as method and substance for the present article.

In the sequence, the reasons of the Court that substantiated the refusals will be verified having judicial dialogues as a theoretical reference. Differing from the vast majority of the academic production, which refers to the responsiveness of the States in the exercise of conventionality control, here, the point of departure for the study of judicial dialogues is in the opposite direction: the Inter-American Court will be put at the center of the discussions.

Two attributes of vertical judicial dialogues will be highlighted: reciprocity and the possibility of divergence. Some reflections about the silence of the Inter-American Court regarding democratic values and the deference granted to the member States in the two rejections of requests for advisory opinions will be presented. Judicial dialogues will be defended as a necessary tool to refrain some movements of democratic setbacks in Latin America.

Final - but not definitive - considerations will be presented. 


\section{Advisory Opinions before the Inter- American Court of Human Rights}

Advisory opinions are relevant assets of international jurisdiction. They were means for the consolidation of international tribunals when they were first established and acted as tools to prevent the inaction of these bodies. These opinions can trigger the attention of a court irrespective of the consent of the parties that are submitted to its jurisdiction. Advisory opinions approach the most diverse subjects of International Law and their requests, even if formulated in an abstractive manner, derive from a controversy and the factual situation that gives rise to it. ${ }^{1}$

The Inter-American System of Human Rights is a reflection of the relevance of advisory opinions. The first decision of the Inter-American Court of Human Rights (henceforth Inter-American Court or Court) was an advisory opinion from 1982. In fact, until the preliminary exceptions' judgment of its first contentious case, in $1987^{2}$, the Court had decided on eight of its current twenty-five advisory opinions. ${ }^{3}$

Article 64 of the American Convention on Human Rights (henceforth American Convention) provides that the Inter-American Court is competent to issue advisory opinions regarding (i) the interpretation of the American Convention and other treaties concerning the protection of human rights in the Americas and (ii) the compatibility of any domestic legislation of a member State of the Organization of American States (henceforth OAS) with the aforementioned instruments.

The same article also determines who is legitimate to request an advisory opinion to the Inter-American Court: (i) member States of the OAS and (ii) the organs of the OAS listed in Chapter X of the Organization's Charter, as well as the Inter-American Commission on Human Rights (henceforth Inter-American Commission). The Rules of Procedure of the Court establish that when "the advisory opinion is sought by an OAS organ other than the Commission; the request shall

RUNAVOT, Marie-Clotilde. La compétence consultative des juridictions internationales:reflet des vicissitudes de la fonction judiciaire internationale. Paris: L.G.D.J., 2010. p. 45-46.

2 IACRHR. Case of Velásquez. Rodriguez v. Honduras. Preliminary objections. Judgment of June $26^{\text {th }}, 1987$. Serie C, n. 1.

RUNAVOT, Marie-Clotilde. La compétence consultative des juridictions internationales:reflet des vicissitudes de la fonction judiciaire internationale. Paris: L.G.D.J., 2010. p. 38. also specify how it relates to the sphere of competence of the organ in question". Therefore, there must be a material connection between the subject of the request and the work of the organ. ${ }^{4}$

The reading of article 64 entails an important conclusion: The Inter-American Court is entitled to a broad mandate when it comes to the elaboration of advisory opinions. Indeed, the Court disposes of a wide material spectrum of analysis, confirmed by its first advisory opinion, in 1982, which stated that the Court has the broadest advisory function ever attributed to an international court. ${ }^{5}$ The Court established that it has competence to take into consideration any treaty regarding the protection of human rights applicable to the American States, even if the treaty has as parties States extraneous to the Inter-American System. This also means that the Court is not restricted to the Inter-American corpus iuris to exercise its advisory function.

A comparison to other international tribunals corroborates this conclusion. The International Court of Justice (henceforth ICJ), for instance, may give an advisory opinion "on any legal question". However, States are not allowed to request an advisory opinion to the ICJ. According to article 96 of the United Nations Charter, the United Nations General Assembly and Security Council are legitimate to trigger the ICJ's advisory function. Besides, the General Assembly can authorize other United Nations organisms and specialized bodies to request advisory opinions "arising within the scope of their activities"7. Despite the procedural differences, the Inter-American Court's advisory opinions frequen-

$4 \quad$ Articles 64-69. IACRHR. Rules of procedure. Approved by the Court during its LXXXV Regular Period of Sessions, held from November 16 to 28, 2009. Available at: http://www.corteidh.or.cr/ sitios/reglamento/nov_2009_ing.pdf. Access on: 10 jun. 2019.

IACRHR. Other treaties subject to the consultative jurisdiction of the Court (Art. 64 American Convention on Human Rights). Advisory Opinion OC-1/82 of September 24, 1982. Series A, n. 1, paragraph 16.

Article 65 of the Statute of the International Court of Justice. Available at: https://www.icj-cij.org/en/statute. Access on: 10 jun. 2019.

Article 96(2) of the United Nations Charter. The General Assembly authorized four United Nations organisms to request advisory opinions to the ICJ: ECOSOC, Trusteeship Council, Interim Committee of the General Assembly, and Committee on Applications for Review of Administrative Tribunals Judgments. Only four of the sixteen specialized agencies authorized to request advisory opinions have done so: UNESCO, WHO, FAO, and the International Maritime Organization. In: ICJ. International Court of Justice: handbook. The Hague: International Court of Justice, 2013. p. 82. 
tly and explicitly refer to the ICJ's case law. ${ }^{8}$

Regarding the European Court of Human Rights (henceforth European Court), Protocol n. 2 of 1963 to the Convention for the Protection of Human Rights and Fundamental Freedoms (European Convention on Human Rights) conferred upon the Court competence to render advisory opinions. However, the legitimacy to present a request and the reach of the Court's analysis were very restricted: only the Committee of Ministers was legitimate to make the requirement and the advisory opinion could "not deal with any question relating to the content or scope of the rights or freedoms" provided by the Convention and its Protocols, but only to the interpretation of these instruments.

The content of Protocol n. 2 was endorsed by Protocol n. 11 of 1994, which modified articles 47 and 48 of the European Convention to include the Court's advisory competence. ${ }^{10}$ One shall notice that the first advisory opinion of the European Court was delivered only in $2008^{11}$, which indicates that the advisory function is not at the heart of the European System.

In August 2018, Protocol n. 16 to the European Convention on Human Rights entered into force and expanded the Court's advisory competence. It determines that the highest courts of the contracting States may request the European Court to give advisory opinions on questions related to the interpretation or application of the rights defined in the European Convention and its protocols. The highest courts are allowed to request advisory opinions only in the context of a pending case before them, which demonstrates that the advisory function is quite restrict. ${ }^{12}$

8 RUNAVOT, Marie-Clotilde. La compétence consultative des juridictions internationales:reflet des vicissitudes de la fonction judiciaire internationale. Paris: L.G.D.J., 2010. p. 90.

9 COUNCIL OF EUROPE. Protocol n. 2 to the Convention on the Protection of Human Rights and Fundamental Freedoms. Council of Europe Treaty Series n. 44. Strasbourg, 1963. Available at: https://www. echr.coe.int/Documents/Library_Collection_P2_ETS044E_ENG. pdf. Access on: 10 jun. 2019.

10 COUNCIL OF EUROPE. Protocol $n .11$ to the Convention on the Protection of Human Rights and Fundamental Freedoms. Council of Europe Treaty Series n. 155. Strasbourg, 1994. Available at: https:// www.echr.coe.int/Documents/Library_Collection_P11_ETS155E_ENG.pdf. Access on: 10 jun. 2019.

11 RUNAVOT, Marie-Clotilde. La compétence consultative des juridictions internationales:reflet des vicissitudes de la fonction judiciaire internationale. Paris: L.G.D.J., 2010. p. 56.

12 COUNCIL OF EUROPE. Protocol n. 16 to the Convention on the Protection of Human Rights and Fundamental Freedoms. Council of Europe Treaty Series n. 214. Strasbourg, 2013. Available at: https://
The Inter-American Court's advisory function is non-litigious and multilateral. ${ }^{13}$ This means that the decisions might be of a relevance that encompasses all the OAS member States, not relating to any specific factual matter. The interpretation given by the Court concerning the human rights protection in the region needs to be pertinent to the Inter-American System as a whole, reason why the advisory function is abstract in its nature - even if the request derives from concrete violations of the American Convention.

Neither the American Convention nor the Inter-American Court Rules of Procedure specify the legal nature of the advisory opinions. According to Jorge Ernesto Roa ${ }^{14}$, from the reasoning of the Court's decisions it is also impossible to apprehend the binding force of the opinions. The author comments that a negative definition is plausible: the advisory opinions do not have the same effects of the sentences delivered by the Court.

This means that the effects provided by article 68 of the American Convention applicable to the sentences are not extendable to its advisory opinions: the obligation of the States parties to implement the sentence and the possibility of execution of the sentence through the domestic mechanisms opposable to the State (execution of decisions against the State). ${ }^{15}$ The contours of the binding effects of the Court's advisory opinions will be discussed in the following section of this article.

From 1982 to present, the Inter-American Court has delivered twenty-five advisory opinions, nineteen of which were requested by member States of the OAS, whilst six were required by the Inter-American Commission. In fourteen of the opinions, the Court dealt with the interpretation and application of human rights provisions; in nine occasions, the Court defined and clarified procedural aspects of the Inter-American System,

www.echr.coe.int/Documents/Protocol_16_ENG.pdf. Access on: 10 jun. 2019.

13 ROA, Jorge Ernesto. La función consultiva de la Corte Interamericana de Derechos Humanos. Temas de Derecho Público n. 94. Instituto de Estudios Constitucionales Carlos Restrepo Piedrahita. Bogotá: Universidad Externado de Colombia, 2015. p. 64.

14 ROA, Jorge Ernesto. La función consultiva de la Corte Interamericana de Derechos Humanos. Temas de Derecho Público n. 94. Instituto de Estudios Constitucionales Carlos Restrepo Piedrahita. Bogotá: Universidad Externado de Colombia, 2015. p. 99.

15 ROA, Jorge Ernesto. La función consultiva de la Corte Interamericana de Derechos Humanos. Temas de Derecho Público n. 94. Instituto de Estudios Constitucionales Carlos Restrepo Piedrahita. Bogotá: Universidad Externado de Colombia, 2015. p. 99. 
mainly the role exercised by the Inter-American Commission; in two of the advisory opinions, the Court was required to analyze the (in)compatibility of domestic legislation with internationally protected human rights.

An interesting aspect of the consultative function of the Inter-American Court is that the American Convention silences about the possibility of refusal of a request for an advisory opinion. The Convention only says that the Court "may provide" opinions ${ }^{16}$, adopting a permissible language. However, it does not forbid the Court to consider that its advisory function has a facultative nature, which means that the Court can answer or not such a request. ${ }^{17}$ Therefore, the Court is allowed to decide, on a discretionary basis, whether to admit or not an advisory opinion, as long as it presents justifications. ${ }^{18}$

In five ${ }^{19}$ occasions, the Court decided to reject a request for an advisory opinion. ${ }^{20}$ Although the background and the motivations that led to the solicitations are different, the Court has developed some criteria for the acceptance or not of a request: (i) the petition must not cover up a contentious case, nor intend to obtain a premature ruling of the Court over a matter that may be submitted before its contentious function; (ii) must not be a mechanism for the obtainment of an indirect decision of the Court regarding a domestic controversy; (iii) must not be used as an instrument for the debate of domestic political matters; (iv) must not

16 Article 64.2. IACHR. American Convention on Human Rights. Adopted at the Inter-American Specialized Conference on Human Rights. San José, 1969. Available at: https://www.cidh.oas.org/basicos/english/basic3.american $\% 20$ convention.htm. Access on: 10 jun. 2019.

17 PAÚL, Álvaro. Rechazo de solicitudes de opinión consultiva por parte de la Corte Interamericana de Derechos Humanos. Revista Chilena de Derecho y Ciencia Politica, p. 119-131, ene./mayo 2017. p. 120.

18 ROA, Jorge Ernesto. La función consultiva de la Corte Interamericana de Derechos Humanos. Temas de Derecho Público n. 94. Instituto de Estudios Constitucionales Carlos Restrepo Piedrahita. Bogotá: Universidad Externado de Colombia, 2015. p. 70.

19 These five occasions do not include the matter of Viviana Gallardo and others: IACRHR. In the Matter of Viviana Gallardo et al. Series A. n. 101.

20 IACRHR. Rejection to the Request of an Advisory Opinion submitted by Costa Rica. Order of May $10^{\text {th }}, 2005$; IACRHR. Rejection to the Request of an Advisory Opinion submitted by the Inter-American Commission of Human Rights. Order of June 24 $4^{\text {th }}$, 2005; IACRHR. Rejection to the Request of an Advisory Opinion submitted by the Inter-American Commission of Human Rights. Order of January $27^{\text {th }}$, 2009; IACRHR. Rejection to the Request of an Advisory Opinion submitted by the Secretary General of the Organization of American States. Order of June, 23 ${ }^{\text {rd }}$, 2016; IACRHR. Rejection to the Request of an Advisory Opinion presented by the Inter-American Commission of Human Rights. Order of May 29 $9^{\text {th }}, 2018$. refer exclusively to subjects already dealt by the Court in its case law; (v) must not aim to solve factual questions, but to clarify the meaning and purpose of international human rights norms. ${ }^{21}$

\section{Judicial dialogues as method and substance}

The posture of the Inter-American Court regarding the refusal of advisory opinions requires an analysis as of the theorizations about judicial dialogues, here understood in a broader scope than the citation of judicial decisions from (and between) different tribunals. What is proposed is the conception of dialogues as conversations between the Inter-American Court and its member States, conversations that are not restricted to the exchange of judicial decisions, but that encompass the reactions of one actor towards the other.

According to the classic theory of Anne-Marie Slaughter, the networks built between different government units can lead, in the judiciary branch, to transjudicial communications between national and supranational courts, with different functions and levels of reciprocity. ${ }^{22}$

These interactions are commonly understood as vertical dialogues. ${ }^{23}$ This verticality is a result of the conventional relationship between the international and the national courts due to the international convention that bounds them. The literature presents critics to this viewpoint, since the verticality usually entails some sort of superiority of the international court over the national institutions ${ }^{24}$, as if the international arena always had the "last word". 25

21 IACRHR. Rejection to the Request of an Advisory Opinion submitted by the Secretary General of the Organization of American States. Order of June $23^{\text {rd }}$, 2016. paragraph 6.

22 SLAUGHTER, Anne-Marie. A typology of transjudicial communication. University of Richmond Law Review, v. 29, n. 99, p. 99-137, 1994. p. 101.

23 For the objectives of this article, the distinction between vertical and horizontal dialogues refers to the existence of an international convention between the tribunals, in the first case, and the absence of it, in the second.

${ }^{24}$ BURGORGUE-LARSEN, Laurence. A internacionalização do diálogo dos juízes: missiva ao Sr. Bruno Genevois, Presidente do Conselho de Estado da França. Prismas: Direito, Políticas Públicas e Mundialização, v. 7, n. 1, p. 80, 2010. Availabe at: www.publicacoesacademicas.uniceub.br. Access on: 15 ago. 2016.

25 FACHIN, Melina; NOWAK, Bruna. Quem dá a última palavra? 
When it comes to human rights, an additional challenge is included: the space left to the States in what concerns the protection of these rights. Until which extension are States allowed to build the content of internationally protected human rights? This question is usually answered with a condition: it depends on the degree of receptivity ${ }^{26}$ of the domestic legal orders regarding International Human Rights Law, also known as "levels of intensity".

Eduardo Ferrer Mac-Gregor explains that the highest levels of intensity take place in countries with a solid constitutional heritage that incorporates the Inter-American corpus iuris in the national legal systems, mainly within constitutional States. ${ }^{27}$ In this sense, for a better harmonization ${ }^{28}$ of the human rights protection, national judges need to apply the standards of the Inter-American System on Human Rights.

This approach of judicial dialogues is focused on the States. The parameters of analysis aim to investigate the responsiveness of the domestic legal orders regarding International Human Rights Law. Therefore, it is possible to measure - and even classify ${ }^{29}$ - the responsive conducts of the States in more or less opened to the international standards.

Without ignoring the extreme importance of these studies about judicial dialogues, this article proposes a different departure for the analysis, having the Inter-American Court at the center. As of the inversion of the point of reference, the reactions of the Court when invited to pronounce itself on matters related to democratic setbacks in its member States are studied. The re-

As relações da Corte Interamericana de Direitos Humanos com os ordenamentos jurídicos nacionais à luz do caso Fontevecchia e D'Amico v. Argentina. In: SILVA, Fernando Quadros da; SARLET, Ingo Wolfgang (coord.). Direitos humanos na contemporaneidade. Curitiba: Instituto Memória, 2018.

26 MAC-GREGOR, Eduardo Ferrer. What do we mean when we talk about judicial dialogue? Reflections of a judge of the InterAmerican Court of Human Rights. Harvard Human Rights Journal, v. 30, 2017. p. 110 .

27 MAC-GREGOR, Eduardo Ferrer. What do we mean when we talk about judicial dialogue? Reflections of a judge of the InterAmerican Court of Human Rights. Harvard Human Rights Journal, v. 30, 2017. p. 109.

28 MAC-GREGOR, Eduardo Ferrer. What do we mean when we talk about judicial dialogue? Reflections of a judge of the InterAmerican Court of Human Rights. Harvard Human Rights Journal, v. 30, 2017. p. 127.

29 SOLEY, Ximena; STEININGER, Silvia. Parting ways or lashing back? Withdrawal, backlash and the Inter-American Court of $\mathrm{Hu}-$ man Rights. Max Planck Research Paper Series n. 2018-01, p. 1-26, 2018. jections of the requests of the two advisory opinions are, in this sense, the starting point.

For the objectives of this article, two of these rejections will be studied, since their substance is related to alleged threats to the democratic order in some countries of the region.

Unlike the European System that had the inseparable triad of rule of law, democracy, and human rights as its inspiring source, the Inter-American System has its origin in the paradox of being born in an authoritarian environment, which did not allow any direct and immediate association between the aforementioned triad. Furthermore, in this context, human rights were traditionally conceived as an agenda against the State. The region still lives with the reminiscences of the legacy of authoritarian dictatorial regimes, with a culture of violence and impunity.

\section{Request for advisory opinion from May 2016: the impeachment process against Dilma Roussef}

On May $16^{\text {th }}, 2016$, a request for an advisory opinion was presented by the Secretary General of the OAS to the Inter-American Court about some aspects that could affect the due process guarantees in political judgments, more specifically, the impeachment process against former Brazilian President Dilma Rousseff. The solicitation referred to the consequences of the following questions:

(i) the declarations of the responsible for voting for the opening of an impeachment process that contain pre-judgment statements for the condemnation or acquittal or that contain justifications extraneous to the cause;

(ii) the recognition, by the same responsible persons, of their submission to instructions that affect their impartiality;

(iii) the adoption of common justifications against one public server;

(iv) the indictment for facts that could have been practiced before the legal time frame under consideration.

The request aimed to obtain a manifestation of the 
Court about the legality of the reasons invoked to initiate a political judgment against President Rousseff, as well as the alleged defects that occurred during the session of the Brazilian Deputy's Chamber that decided to authorize the processing of the impeachment by the Senate.

Two interesting observations were made by the Inter-American Court in its decision of refusal to deliver the advisory opinion. Firstly, the OAS Secretary General did not individualize the international provisions regarding which interpretation was been required. The Court preferred to refuse the request based on the merits of the solicitation, setting aside this formal criterion that was not followed. ${ }^{30}$

Secondly, the Secretary General understood that an advisory opinion by the Court would be necessary for the application of article 20 of the Inter-American Democratic Charter.

The Inter-American Democratic Charter ${ }^{31}$ was adopted in 2001 in recognition of the Organization's role to promote and consolidate representative democracy in the region. So far, the Charter has not been applied to impeachment cases. ${ }^{32}$ Its article 19 is known as a democratic clause ${ }^{33}$ which establishes that an unconstitutional interruption or change in the constitutional or democratic regime in a member State constitutes an obstacle to its participation in sessions and meetings of the Organization's organisms.

In this sense, article 20 provides that, in such an event, any member State or the Secretary General may request the convocation of the Permanent Council of the OAS to assess the situation and take the necessary measures to restore democracy. If these diplomatic actions are not successful, the Permanent Council shall convene a special session of the General Assembly.

Article 21 of the Charter establishes that, when

\footnotetext{
30 PAÚL, Álvaro. Rechazo de solicitudes de opinión consultiva por parte de la Corte Interamericana de Derechos Humanos. Revista Chilena de Derecho y Ciencia Politica, p. 119-131, ene./mayo 2017. p. 126.

31 OAS. Inter-american democratic charter. Lima, 2001. Available at: https://www.oas.org/charter/docs/resolution1_en_p4.htm. Access on: 10 jun. 2019.

32 BAILLIET, Cecilia M. The strategic prudence of the InterAmerican Court of Human Rights: rejection of requests for an advisory opinion. Revista de Direito Internacional, Brasília, v. 15, n. 1, p. 254-276, 2018. p. 274.

33 This democratic clause was accorded by the OAS member States in the Declaration of Quebec City of April 2001.
}

there has been an unconstitutional interruption of the democratic order of a member State, and the diplomatic initiatives have failed, the special session can decide to suspend this State from the exercise of its right to participate in the OAS. Affirmative votes of two-thirds of the OAS member States are necessary for the suspension, which takes effect immediately. The article also determines that the suspended State shall continue to comply with its obligations as an OAS member, in particular regarding human rights.

The Court stated that the faculty provided by article 20 of the Democratic Charter can be exercised by the OAS Secretary General in a discretionary basis according to his evaluation of the situation. This faculty is beyond the Court's advisory function and was not decisive to the rejection. ${ }^{34}$

The fact that the impeachment process against President Rousseff was still under consideration by the Brazilian Senate led the Inter-American Court to decide that, if it elaborated an advisory opinion, it would constitute a premature analysis of a matter that could be brought before its contentious jurisdiction, especially because the issue was not domestically concluded. ${ }^{35}$

Theorizations about judicial dialogues reveal that this argument of the Court was not a simple repetition of the reasoning of its previous decisions. Whether vertical or horizontal, dialogues presuppose a genuine exchange between the interlocutors. Without this confluence of ideas, the conversations are one-sided. This attribute of dialogues can be named as reciprocity ${ }^{36}$ and requires a proper response from one organ in relation to the other.

In the two advisory opinions, the Court was urged to manifest itself about a delicate subject, since "impeachment is a marker of institutional instability and inter-branch conflict." ${ }^{37}$ Therefore, a detailed look at some of the questions presented before the Court allows one

\footnotetext{
34 IACRHR. Order of June $23^{\text {rd }}$, 2016, paragraph 8.

35 IACRHR. Order of June 23 $3^{\text {rd }}$, 2016, paragraph 7.

36 NOWAK, Bruna. Entre diálogos e monólogos: um estudo sobre as referências da Corte Internacional de Justiça à jurisprudência das cortes regionais de direitos humanos. 2018. 209 f. Dissertação (Mestrado em Direito) - Faculdade de Direito, Universidade Federal do Paraná, Curitiba, 2018. f. 45-47.

37 BAILLIET, Cecilia M. The strategic prudence of the InterAmerican Court of Human Rights: rejection of requests for an advisory opinion. Revista de Direito Internacional, Brasília, v. 15, n. 1, p. 254-276, 2018. p. 269.
} 
to conclude that, indeed, an advisory opinion was not the most suited sphere for the required answers. For instance, how could the Court decide about the legality of the reasons invoked to initiate a political judgment against former President Rousseff?

In this sense, what is important to consider about reciprocity is that it entails the confluence of ideas between the interlocutors. In the present situation, the Inter-American Court considered the States able to better contribute to the solution of these questions. The ideal scenario would be an interaction between the legal orders: the States' courts using the decisions of the Inter-American Court of Human Rights as parameters to define the contours of political trials.

As the Inter-American Court has given the first steps into this direction, a response from the States is expected. This behavior would constitute a genuine dialogue between the two legal orders, especially when one considers the sensitivity of the subjects involving impeachment proceedings. This analysis will continue in the second refusal of a request for an advisory opinion.

\section{Request for advisory opinion from October 2017: the guarantees of due process in impeachment proceedings}

On October $13^{\text {th }}, 2017$, the Inter-American Commission requested an advisory opinion to the Inter-American Court about the guarantees of due process and the principle of legality in the context of impeachment proceedings against constitutional and democratically elected presidents, as well as the potential implications the arbitrary use of this mechanism entails to the exercise of human rights. ${ }^{38}$

One peculiar aspect of this case is that the Court had firstly initiated the proceedings and allowed the presentation of amicus curiae briefs. The suspension of the processing of the request happened later, and the Court established that it has the authority to decree the suspension at any time.

Indeed, the declaration of inadmissibility of an advisory opinion can take place in two different procedural moments: before or after the Court observes article 73.1

$\overline{38}$ IACRHR. Order of June 23 $3^{\text {rd }}$, 2016, paragraph 3. of its Rules of Procedure, which establishes that it must send a copy of the request to all of the OAS member States, the Inter-American Commission and other OAS organisms, so they can present written observations. ${ }^{39}$

The Court had already adopted this behavior - of issuing the decision of inadmissibility after the application of article 73.1 of the Rules of Procedure - in two previous requests of advisory opinion, one regarding the compatibility of a legislative amendment in Costa Rica in relation to article 8 of the American Convention $^{40}$, and the other about the compatibility of the Convention with measures that denied access to appeals in cases concerning death penalty ${ }^{41}$.

In the first decision, the Court understood that if it answered the request, it "could in the long run interfere with cases that should be fully processed by the Commission" 42 . In the second decision, the Court received observations from States and organizations that opposed to the admissibility of the request. The Court considered that it had already decided on the imposition of the death penalty and its implementation in contentious and advisory cases.

Considering this background, the Inter-American Court indicated that the Inter-American Commission was processing three individual petitions about political judgments: alleged human rights violations against Manuel Zelaya in the context of the coup d'etat in Honduras; against Fernando Lugo in the context of the impeachment proceedings in Paraguay; and against President Rousseff. Again, the Court understood that delivering an advisory opinion would correspond to a premature decision on cases being processed before its contentious jurisdiction. ${ }^{43}$

The Court affirmed that the provisions about impeachment proceedings and political trials substantially vary among the Constitutions of the OAS member Sta-

\footnotetext{
39 PAÚL, Álvaro. Rechazo de solicitudes de opinión consultiva por parte de la Corte Interamericana de Derechos Humanos. Revista Chilena de Derecho y Ciencia Politica, p. 119-131, ene./mayo 2017. p. 127.

40 IACRHR. Compatibility of draft legislation with Article 8.2.h of the American Convention on Human Rights. Advisory Opinion OC-12/91 of December 6, 1991. Series A, n. 12.

41 IACRHR. Request for an advisory opinion presented by the Inter-American Commission on Human Rights. Order of the Inter-American Court of Human Rights of June 24, 2005.

42 IACRHR. Advisory Opinion OC-12/91 of December 6, 1991. paragraph 29.

43 IACRHR. Order of May 29 ${ }^{\text {th }}, 2018$, paragraphs 7-8.
} 
tes. In this sense, it would be "very difficult to reduce the Inter-American standards to a minimum common denominator in order to respond to the questions posed by the Commission" ${ }^{44}$.

In the light of the attribute of reciprocity, this argument demonstrates that one interlocutor needs to take the other as reference, in order to "recognize the importance of the institution considered as a [decisional] parameter and the contributions that come from $\mathrm{it}{ }^{\prime 4}$. In the present two cases, the Inter-American Court made expressed reference to the Latin-American context about political trials, specifying that the diversity of the legal orders was an obstacle to the delivery of a complete and coherent advisory opinion.

It is interesting to observe that the Court proposed a (hardly achievable) criterion to analyze requests of advisory opinions, in order to find a balance between mere abstractions and factual matters:

\begin{abstract}
Nevertheless, requests for an advisory opinion should not be so specific that they involve deciding a contentious case in disguise, or the prejudgment of specific situations. Thus, the goal is to achieve the difficult balance between the legitimate interests of the party requesting the opinion and the general purpose of the advisory function. ${ }^{46}$
\end{abstract}

Again, theorizations about dialogues explain the Inter-American Court's approach, since this balance can be better achieved through reciprocity, in the sense that the Court shall give more weight to the reasons invoked by the requesting part of an advisory opinion, as well as to the extension of the effects the advisory opinion might achieve.

The recognition of the legitimate interests behind the proposition of a request for an advisory opinion reinforces the richness of judicial dialogues. Even if the Court decides to abstain from giving an answer - which is exactly the scenario -, considering the particularities the interlocutor is fundamental to establish the confluence of arguments triggered by dialogues. Reciproci-

\footnotetext{
44 IACRHR. Order of May 29 $9^{\text {th }}, 2018$, paragraph14.

45 Tradução livre. "Dialogar, mais do que tomar emprestadas sentenças de outra instância ou responder timidamente a estes empréstimos, significa reconhecer a importância da instituição de que se vale como parâmetro e as contribuições dela advindas". In: NOWAK, Bruna. Entre diálogos e monólogos: um estudo sobre as referências da Corte Internacional de Justiça à jurisprudência das cortes regionais de direitos humanos. 2018. 209 f. Dissertação (Mestrado em Direito) - Faculdade de Direito, Universidade Federal do Paraná, Curitiba, 2018. f. 46.

46 IACRHR. Order of May 29 $9^{\text {th }}, 2018$, paragraph 9.
}

ty means not only opening the floor to the interlocutor but also taking into account the diversity and plurality of ideas that come from this connection.

The Court then concluded that the wording of the request it received was not compatible to this balance, because the Commission referred to "possible distortions of the impeachment mechanism" that could entail a "parliamentary coup d'état. ${ }^{47}$ The request was too close to factual situations.

An interesting feature is that, if the Court were willing to, if could have used an asset to revert the (allegedly) excessively factual request and elaborate the advisory opinion. In paragraph 17 of the Order of May $29^{\text {th }}, 2018$, the Court declares that:

17. Based on the above, the Court finds that, by responding to the Inter-American Commission's questions as they are worded - that is, developing abstract considerations on the compatibility of the numerous models of impeachment - it could not sufficiently examine the particularities of the institutional design of the different horizontal control mechanisms that exist in the region.

The Court affirms that the examination of the Inter-American Commission's questions "as they were worded" would result in "abstract considerations on the compatibility of the numerous models of impeachment". In order to avoid abstractions, the Court decided to overrule the request, aiming to preserve the "particularities of the institutional design of the different horizontal control mechanisms that exist in the region".

What the court decided to omit is the possibility established by its own case law - it has to change the wording of the questions presented before it. Jorge Ernesto Roa adduces that the entities that consult the Court through its advisory function carry the responsibility to present their requests with clarity. Since this scenario does not always occur, the Court has decided that within its competence is the authority to reformulate the questions that compose the requests of advisory opinions. The Inter-American Court so determined in its Advisory Opinion $n^{\circ} 7$ of 1986, designating that it can interpret, clarify, and redefine the questions proposed before it. ${ }^{48}$

\footnotetext{
47 IACRHR. Order of May 29 $9^{\text {th }}, 2018$,paragraph 13.

48 ROA, Jorge Ernesto. La función consultiva de la Corte Interamericana de Derechos Humanos. Temas de Derecho Público n. 94. Instituto de Estudios Constitucionales Carlos Restrepo Piedrahita. Bogotá: Universidad Externado de Colombia, 2015. p. 79.
} 
For instance, in the most recent advisory opinion elaborated by the Court, $\mathrm{n}^{\circ} 25$ of 2018, it affirmed that the questions presented by the State of Ecuador contained factual issues. For this reason, the Court recalled that its advisory function constitutes a service in favor of all the Inter-American States. It decided that it could not respond the request in the exact terms proposed, since the questions did not refer exclusively to questions of interpretation of human rights treaties and required the definition of factual background. ${ }^{49}$ The Court reformulated the questions in order to properly formulate the advisory opinion.

The Court's decision not to use this faculty in the two requests under consideration was a discretionary choice. In the context of judicial dialogues, this omission is not a total silence of the Court. It was a strategic move that corroborated the non-delivery of the advisory opinions. If it wanted, the Court could have presented contrapositions to the questions and proposed a more adequate wording for the exercise of its advisory function.

In this sense, it is important to highlight that the contraposition of ideas is not an opposition to dialogues. Dialogues do not necessary produce consonance; they are also able to create dissonance. ${ }^{50}$ In fact, if dialogues were meant only to generate agreement, a lot of potential would be lost. ${ }^{51}$ Dialogical relations between different actors, especially tribunals, can entail an "informative discordance", which means that the final disagreement will be a product of reflection and consideration of the position rejected.

\footnotetext{
49 IACRHR. The institution of asylum, and its recognition as a human right under the Inter-American System of Protection (interpretation and scope of Articles 5, 22(7) and 22(8) in relation to Article 1(1) of the American Convention on Human Rights). Advisory Opinion OC 25/18 of May 30 $0^{\text {th }}$, 2018. Series A, n. 25, paragraph 54.

50 NOWAK, Bruna. Entre diálogos e monólogos: um estudo sobre as referências da Corte Internacional de Justiça à jurisprudência das cortes regionais de direitos humanos. 2018. 209 f. Dissertação (Mestrado em Direito) - Faculdade de Direito, Universidade Federal do Paraná, Curitiba, 2018. f. 50.

51 Aristoteles Constantinides comments that the search for coherence might not ignore other values, such as the potential that comes from divergences and that makes the decision-making process less restrict to the particularities from where the decision is taken. In: CONSTANTINIDES, Aristoteles. Transjudicial dialogue and consistency in human rights jurisprudence: a case study on diplomatic assurances against torture. In: FAUCHALD, Ole Kristian; NOLLKAEMPER, André (ed.). The practice of international and national courts and the (de-)fragmentation of international law. Oregon: Hart Publishing, 2012. p. 273-274.
}

Substantially speaking, what the Court could have said, but decided not to, is that it has the duty not to interfere in domestic political issues. This would constitute a cautious move in line with a dialogical behavior. However, the Court opted to expose justifications in consonance to its previous decisions of refusal of advisory opinions. In the language of judicial dialogues, this omission is not a simple passive posture of the Court. The Court's refusals were not a mere "no": behind the apparent silence, there is much that can be apprehended. The refusal does not make the Court "mute" 52 about the subject, as will be further explained.

What can be seen from the above is that the occasions in which the Inter-American Court chose to silence tell a great deal about the organism's cosmology about its own advisory jurisdiction and on what terms it should be delineated.

The justifications presented by the Court in both of the decisions resonate in relation to the theorizations about judicial dialogues. They are a sign of reciprocity, in the sense that the Inter-American Court recognized that the States were the best arena for the discussions. This recognition was only possible because the domestic legal orders were taken into account; otherwise, there would be no reciprocity: the Court would have simply rejected the requests - as it is allowed to do.

As the theorizations about judicial dialogues add light to some specific contours of the Court's two decisions and demonstrate that there was more than a simply refusal to comment on democracy in the region, extra comments are necessary when one verifies that the Court has an expansive posture regarding its advisory function.

\section{Expansiveness and deference: $a$ space for dialogues}

As seen in the first section of this article, the effects and limits of the Inter-American Court's advisory func-

\footnotetext{
52 "The main feature of dialogue is the necessity for an exchange of ideas between those engaged init; otherwise it is rather a monologue". In: TZANAKOPOULOS, Antonios. Judicial dialogue in multilevel governance: the impact of the Solange argument. In: FAUCHALD, Ole Kristian; NOLLKAEMPER, André (ed.). The practice of international and national courts and the (de-)fragmentation on international law. Oxford, Portland: Hart Publishing, 2012. p. 188.
} 
tion are blurry. What can be observed is continuous expansion in the exercise of this function. The Court has constantly mentioned that the effects of its advisory opinions are undeniable ${ }^{53}$, even if they differ from the binding nature of its sentences. According to Marie-Clotilde Runavot, the absence of a mandatory legal force does not entail the practical inutility or the illusory character of advisory opinions. ${ }^{54}$

If, in the beginning of the exercise of its jurisdiction, the Court answered requests about procedural aspects of the Inter-American System, in the past few years (more precisely since 2014), the Court has come across requests related to substantial matters of International Human Rights Law. Just like the two requests that were refused, the Court has received other solicitations that were long, more complex, and referred to the interpretation and application of human rights norms.

For example, in the Advisory Opinion $n^{\circ} 21$ of $2014^{55}$, the Court pronounced itself about the States' international obligations regarding the rights of children in the context of migration. In order to properly respond to the request, the Court not only searched for the meaning and purpose of the international norms, but aimed to instigate States to implement their obligations and adopt human rights public policies about the subject. The scope of advisory opinions is, therefore, to strengthen the Inter-American System for human rights protection in a manner compatible with the interests of justice. $^{56}$

An important commentary was made by the Court in this advisory opinion. It recognized that the obligations identified by the Court about children in migratory processes are complex and changing in the present times. For this reason, they must be understood as part of the "progressive development of International $\mathrm{Hu}$ -

53 IACRHR. Reports of the Inter-American Commission on Human Rights (Art. 51 American Convention on Human Rights). Advisory Opinion OC-15/97 of November 14, 1997. Series A, n. 15, paragraph 26.

54 Translation by the authors. In the original: «'absence de force juridique obligatoire de tout acte consultatif n'implique donc pas forcément son inutilité pratique ou de caractère illusoire». RUNAVOT, Marie-Clotilde. La compétence consultative des juridictions internationales:reflet des vicissitudes de la fonction judiciaire internationale. Paris: L.G.D.J., 2010. p. 52.

55 IACRHR. Rights and guarantees of children in the context of migration and/or in need of international protection. Advisory Opinion OC 21/14 of August 19 ${ }^{\text {th }}$, 2014. Series A, n. 21.

56 IACRHR. Advisory Opinion OC 21/14 of August 19 $9^{\text {th }}$, 2014. paragraphs 28-29. man Rights Law"57. For Cecilia Bailliet, this practice reveals "the deliberative use of advisory opinions to strengthen the normative evolution of human rights law". According to the author, "these [expansive] cases are balanced by the Court's parallel rejection of requests which address certain political cases and pragmatically signal deference to States" ${ }^{\prime 58}$.

In the Advisory Opinion n 25 of 2018, the Court interpreted some articles of the American Convention to define the content of the institution of asylum as a human right. The Court concluded that, whilst there are precise obligations regarding the right to territorial asylum, there is no customary rule (not even a regional one) about the right to diplomatic asylum. ${ }^{59}$

The development of the Court's advisory function points to an expansion (vis expansiva) of this competence, mainly in what concerns the reach of the decisions. ${ }^{60}$ The Court not only defines the content of rights: it also specifies the States' international obligations and considers the entire international human rights regime, not confining itself to the Inter-American corpus iuris. The Court's advisory opinions play an important role in the development of International Human Rights Law as of the American region.

This vis expansiva has a special nuance in the Inter-American System. Latin America is characterized by a high degree of social exclusion and inequality to which democracies in the consolidation phase are added. It is in this scenario that the System legitimizes itself as an important and effective instrument for the protection of human rights when national institutions prove to be failures or omissions. This is why the Court has a wide repertoire of strengthening the rule of law in the region.

When compared to this expansiveness, can the two decisions of refusal to present advisory opinions be un-

\footnotetext{
57 IACRHR. Advisory Opinion OC 21/14 of August 19 $9^{\text {th }}$, 2014. paragraph 14 of the concluding remarks.

58 BAILLIET, Cecilia M. The strategic prudence of the InterAmerican Court of Human Rights: rejection of requests for an advisory opinion. Revista de Direito Internacional, Brasília, v. 15, n. 1, p. 254-276, 2018. p. 262.

59 IACRHR. The institution of asylum, and its recognition as a buman right under the Inter-American System of Protection (interpretation and scope of Articles 5, 22(7) and 22(8) in relation to Article 1(1) of the American Convention on Human Rights).

60 ROA, Jorge Ernesto. La función consultiva de la Corte Interamericana de Derechos Humanos. Temas de Derecho Público n. 94. Instituto de Estudios Constitucionales Carlos Restrepo Piedrahita. Bogotá: Universidad Externado de Colombia, 2015. p. 102.
} 
derstood as a movement in the opposite direction since the Court decided to restrain itself? What can be apprehended from the present analysis is an opposition between the Court's expansive posture and the space of deference that was given to the member States in the two cases under appreciation.

Deference is an attribute constantly required from the Inter-American Court. In the words of Jorge Contesse, "it may be time to reconsider the system's reluctance toward subsidiarity as a principle of international adjudication" ${ }^{\prime 61}$. The author sustains that a more collaborationist model would help the enforcement of International Human Rights Law, since it would grant States "some say regarding the protection of human rights, as the Court has timidly done recently" $"$.

Acting in a subsidiary way was a conscious choice made by the Court in both of the advisory opinions about political judgments. If the Court wished, it could have given a more assertive response to the requests. It could also have answered both of them, whether it decided to reformulate the questions or not. Any of the aforementioned behaviors would be justified by the discretionary powers and the principle of competence de la compétence.

It is important to note that the incisive decisions taken by the Inter-American Court are, mostly, well grounded on international parameters of human rights' protection. For instance, the Court has a consolidated (contentious) case law regarding the principle of legality in the context of deprivation of liberty. ${ }^{63}$ In the advisory opinions, the Court has developed deep and complete analysis on subjects regulated under International Human Rights Law, such as the protection of the environment, gender equality, migration, and the right to asylum. In these occasions, the Court has established dialogues with other systems for the protections of human rights, mainly the United Nations and the European Court of Human Rights.

${ }^{61}$ CONTESSE, Jorge. Subsidiarity in inter-american buman rights law. p. 25. Available at: https://law.yale.edu/system/files/documents/ pdf/SELA15_Contesse_CV_Eng.pdf. Access on: 30 jun. 2019.

62 CONTESSE, Jorge. Contestation and deference in the InterAmerican Human Rights System. Law and Contemporary Problems, v. 79, n. 2, p. 123-145, 2016. p. 144.

63 IACHR. Informe sobre los Derechos Humanos de las Personas Privadas de Libertad en las Américas. OEA/Ser.L/V/II. Doc. 64. 31 dez. 2011. Available at: http://www.oas.org/es/cidh/ppl/docs/pdf/ PPL2011esp.pdf. Access on: 07 jul. 2019.
There would not be the same robust international legal background for the Court to decide on political trials and impeachment processes. Therefore, the deferential approach can also be understood because of the lack of decisional parameters. However, one cannot forget that the Inter-American Court is not a soloist when it comes to facing political cases. The ICJ, in the exercise of its advisory jurisdiction, has delivered decisions on highly political issues.

For instance, in the advisory opinion about Kosovo's declaration of independence ${ }^{64}$, the ICJ stated that the political aspect of a question is not sufficient to deprive it of its legal character, nor it leads the Court to refuse to respond to the request:

\begin{abstract}
Whatever its political aspects, the Court cannot refuse to respond to the legal elements of a question which invites it to discharge an essentially judicial task, namely, in the present case, an assessment of an act by reference to international law. The Court has also made clear that, in determining the jurisdictional issue of whether it is confronted with a legal question, it is not concerned with the political nature of the motives which may have inspired the request or the political implications which its opinion might have. ${ }^{65}$
\end{abstract}

In the opinion about the construction of a wall in the occupied Palestinian territory ${ }^{66}$, the ICJ has gone beyond the original request - the possible international responsibility of Israel for violating International Law - and extended the analysis to the responsibility of the United Nations and other States. More recently, in the opinion concerning the Chagos Islands, in which the right to self-determination was reaffirmed, the Court decided a highly political and sensitive question and concluded that "the United Kingdom is under an obligation to bring to an end its administration of the Chagos Archipelago as rapidly as possible" ${ }^{\prime 67}$.

64 ICJ. Accordance with international law of the unilateral declaration of independence in respect of Kosovo. Advisory Opinion of 22nd July 2010. Available at: http://www.icj-cij.org/files/ caserelated/141/141-20100722-ADV-01-00-EN.pdf. Access on: 08 apr. 2020.

65 ICJ. Accordance with international law of the unilateral declaration of independence in respect of Kosovo. Advisory Opinion of 22 $2^{\text {nd }}$ July 2010. paragraph 27. Available at: http://www.icj-cij.org/files/ caserelated/141/141-20100722-ADV-01-00-EN.pdf. Access on: 08 apr. 2020.

66 ICJ. Legal consequences of the construction of a wall in the occupied palestinian territory. Advisory Opinion of $9^{\text {th }}$ July 2004. Available at: https://www.icj-cij.org/files/case-related/131/13120040709-ADV-01-00-EN.pdf. Access on: 08 apr. 2020.

${ }^{67}$ ICJ. Legal consequences of the separation of the Chagos Archipelago from Mauritius in 1965. Advisory Opinion of 25 $5^{\text {th }} \mathrm{Feb}-$ 
These brief mentions of the ICJ's decisions highlight the concrete, factual, and political origins of its advisory opinions and show that the Court, unlike the Inter-American, usually chooses to decide on the matters.

Besides, the Inter-American System ordinary approach towards democratic ruptures in its member States takes place through the annual report of the Inter-American Commission on Human Rights. Cuba and Venezuela lead the list of the countries included in Chapter IV of the report, which focuses on examining the countries that face adversary contexts in the protection of human rights or a rupture in its democratic institutions. In addition, there are the mechanisms provided by articles 19 to 21 of the Inter-American Democratic Charter, which, as seen, can culminate in the suspension of member States. ${ }^{68}$

The Court's vis expansiva also leads to another observation. As seen, the advisory opinions of the Inter-American Court have been contributing to the development of International Human Rights Law. The assertiveness of the Court's pronouncements has the potential to generate effects extra-system, in the sense that it can impact the normative evolution of internationally protected human rights outside the Inter-American boundaries. However, the intra-system effects remain limited because the robustness of the advisory opinion does not necessarily trigger more compliance by the member States ${ }^{69}$ : at most, "they are considered to encourage rather than compel state compliance" ${ }^{70}$.

ruary of 2019. Available at: https://www.icj-cij.org/files/caserelated/169/169-20190225-01-00-EN.pdf. Access on: 08 apr. 2020. 68 CERQUEIRA, Daniel. Impericia jurídica, insolencia histórica e incoherencia diplomática: al propósito del manotazo de cinco países de Sudamérica al Sistema Interamericano de Derechos Humanos. Justicia en las Américas: blog de la Fundación para el Debido Proceso, May $3^{\text {rd }}, 2019$. Available at: https://dplfblog.com/2019/05/03/impericia-juridica-insolencia-historica-e-incoherencia-diplomatica-aproposito-del-manotazo-de-cinco-paises-de-sudamerica-al-sistemainteramericano-de-derechos-humanos/. Access on: 20 jun. 2019.

${ }^{69}$ For Jorge Roa, "Un presupuesto del cumplimiento o incumplimiento de una obligación consiste en estar vinculado por la fuente donde se encuentra establecido el deber o la obligación. En el caso de las opiniones consultivas, las fisuras de indeterminación de los efectos y ampliación de la competencia no permiten afirmar con total certeza que los estándares de protección de los derechos humanos establecidos en las decisiones consultivas son de obligatorio cumplimiento para los Estados que hacen parte del Sistema Interamericano". In: ROA, Jorge Ernesto. La función consultiva de la Corte Interamericana de Derechos Humanos. Temas de Derecho Público n. 94. Instituto de Estudios Constitucionales Carlos Restrepo Piedrahita. Bogotá: Universidad Externado de Colombia, 2015. p. 122.

${ }^{70}$ BAILLIET, Cecilia M. The strategic prudence of the Inter-
This means that even if the Court had decided to write the two advisory opinions, they would probably not refrain the democratic setbacks that are taking place in some countries. Therefore, it is possible to approximate the Court's decision "not to decide" to the strategic litigation that characterizes its contentious jurisdiction, in the sense that only the relevant cases capable of impacting the Latin-American region are taken before and decided by the Court.

As one can conclude, behind the deference given to the States is a much more complex decisional rationality adopted by the Inter-American Court. Besides the peculiarities of the advisory jurisdiction, the subject of democratic ruptures is a challenging one. The interconnection between human rights and democracy is not new, and although it is reaffirmed at various times in the contemporary protection of these, it is reminiscent of the category's own modern heritage. Therefore, democracy remains indispensable, even if the Court decides not to talk about it.

\section{Conclusion}

The notion of human rights has, since its liberal enunciation, been deeply related to political power, either in the liberal order with the concern of limiting the State through the guarantee of rights and separation of powers, either in the social order as a gauge of the legitimacy of the political power, based on the realization of rights.

From its modern normative origin, human rights have a strong connection with the political field and with the democratic regime since they are located in the intersection of the political relations of power and domination in the society.

These rights are in the dynamics of relations of contemporary political power, and are, at the same time, guarantee and instrument of the democratic principle in securing the necessary conditions for its exercise. Human rights integrate the entire State legal system as a material foundation, thus functioning as elements of the legitimacy of the political-legal order.

American Court of Human Rights: rejection of requests for an advisory opinion. Revista de Direito Internacional, Brasília, v. 15, n. 1, p. 254-276, 2018. p. 256. 
Democracy, both nationally and internationally, appears as a joint and inseparable condition for the protection of human rights.

Inspired by this conviction, the Inter-American Court rejected two requests for advisory opinions on political trials presented before it, one in 2016 (about former President Dilma Roussef's impeachment) and the other in 2017 (about the guarantees of due process and the principle of legality in the context of impeachment proceedings against constitutional and democratically elected presidents), refraining itself from issuing a viewpoint on the matters.

As previously stated, the silence says a lot, especially about the Court's advisory jurisdiction and vision about its mandate to defend human rights and, by consequence, democracy in our region.

These rejections work as dialogues between the Inter-American Court and its member States. By opting to "say nothing", the Inter-American System is actually entailing a conversation with its member States that is not restricted to the exchange of judicial decisions, but that encompass the dynamics of reciprocity and deference. The omissions of the Court are nothing but strategic and coherent to its previous decisions of rejection of requests of advisory opinions.

Even though the development of the Court's advisory function points to an expansion (vis expansiva) of this competence, the two decisions of refusal to present advisory opinions can be understood as a posture of deference that was given to the member States. These dialogues can do more for democracy in the Latin American region than top-down advisory opinions that put the States as enemies of the System.

Besides, having the Court at the center of the discussion enlightens that it also intended to avoid a possible instrumentalization of its advisory competence: answering contentious cases in disguise without the consent of the parties. In exercising its advisory function, the Inter-American Court cannot interfere, alter or distort its contentious function. However, as seen, this line is tenuous.

Political trials can serve democracy or be prejudicial to it. The two requests of advisory opinions sought a criterion to assess situations in which these judgments are validly exercised and when they are improperly used. The Court's response, read in the light of the theoriza- tions regarding judicial dialogues, points to the need for comparative analysis. This dialogical exercise could lead to conclusions about how judicial control might not imply a risk to the separation of powers and the system of checks and balances and what safeguards there could be to prevent the use of political judgments in the form of a covered-up coup d'etat.

Through dialogues, reciprocity and deference can have better results in democracy and human rights practices in the region.

\section{References}

BAILLIET, Cecilia M. The strategic prudence of the Inter-American Court of Human Rights: rejection of requests for an advisory opinion. Revista de Direito Internacional, Brasília, v. 15, n. 1, p. 254-276, 2018.

BURGORGUE-LARSEN, Laurence. A internacionalização do diálogo dos juízes: missiva ao Sr. Bruno Genevois, Presidente do Conselho de Estado da França. Prismas: Direito, Políticas Públicas e Mundialização, v. 7, n. 1, 2010. Availabe at: www.publicacoesacademicas. uniceub.br. Access on: 15 ago. 2016.

CERQUEIRA, Daniel. Impericia jurídica, insolencia histórica e incoherencia diplomática: al propósito del manotazo de cinco países de Sudamérica al Sistema Interamericano de Derechos Humanos. Justicia en las Américas: blog de la Fundación para el Debido Proceso, May $3^{\text {rd }}$, 2019. Available at: https://dplfblog.com/2019/05/03/ impericia-juridica-insolencia-historica-e-incoherenciadiplomatica-a-proposito-del-manotazo-de-cinco-paises-de-sudamerica-al-sistema-interamericano-de-derechos-humanos/. Access on: 20 jun. 2019.

CONSTANTINIDES, Aristoteles. Transjudicial dialogue and consistency in human rights jurisprudence: a case study on diplomatic assurances against torture. In: FAUCHALD, Ole Kristian; NOLLKAEMPER, André (ed.). The practice of international and national courts and the (de-)fragmentation of international law. Oregon: Hart Publishing, 2012.

CONTESSE, Jorge. Contestation and deference in the Inter-American Human Rights System. Law and Contemporary Problems, v. 79, n. 2, p. 123-145, 2016.

CONTESSE, Jorge. Subsidiarity in inter-american buman rights law. Available at: https://law.yale.edu/system/fi- 
les/documents/pdf/SELA15_Contesse_CV_Eng.pdf. Access on: 30 jun. 2019.

COUNCIL OF EUROPE. Protocol $n .2$ to the Convention on the Protection of Human Rights and Fundamental Freedoms. Council of Europe Treaty Series n. 44. Strasbourg, 1963. Available at: https://www.echr.coe.int/Documents/Library_Collection_P2_ETS044E_ENG.pdf. Access on: 10 jun. 2019.

COUNCIL OF EUROPE. Protocol n. 11 to the Convention on the Protection of Human Rights and Fundamental Freedoms. Council of Europe Treaty Series n. 155. Strasbourg, 1994. Available at: https://www.echr.coe.int/Documents/Library_Collection_P11_ETS155E_ENG.pdf. Access on: 10 jun. 2019.

COUNCIL OF EUROPE. Protocoln. 16 to the Convention on the Protection of Human Rights and Fundamental Freedoms. Council of Europe Treaty Series n. 214. Strasbourg, 2013. Available at: https://www.echr.coe.int/Documents/Protocol_16_ENG.pdf. Access on: 10 jun. 2019.

FACHIN, Melina; NOWAK, Bruna. Quem dá a última palavra? As relações da Corte Interamericana de Direitos Humanos com os ordenamentos jurídicos nacionais à luz do caso Fontevecchia e D'Amico v. Argentina. In: SILVA, Fernando Quadros da; SARLET, Ingo Wolfgang (coord.). Direitos humanos na contemporaneidade. Curitiba: Instituto Memória, 2018.

IACHR. American Convention on Human Rights. Adopted at the Inter-American Specialized Conference on $\mathrm{Hu}-$ man Rights. San José, 1969. Available at: https://www. cidh.oas.org/basicos/english/basic3.american \%20convention.htm. Access on: 10 jun. 2019.

IACHR. Informe sobre los derechos humanos de las personas privadas de libertad en las Américas. OEA/Ser.L/V/II. Doc. 64. 31 dez. 2011. Available at: http://www.oas.org/es/ cidh/ppl/docs/pdf/PPL2011esp.pdf. Access on: 07 jul. 2019.

IACRHR. Case of Velásquez Rodríguez v. Honduras. Preliminary Objections. Judgment of June $26^{\text {th }}, 1987$. Serie C, n. 1.

IACRHR. Compatibility of Draft Legislation with Article 8.2.h of the American Convention on Human Rights. Advisory Opinion OC-12/91 of December 6, 1991. Series A, n. 12.

IACRHR. Other treaties subject to the consultative jurisdiction of the Court (Art. 64 American Convention on
Human Rights). Advisory Opinion OC-1/82 of September 24, 1982. Series A, n. 1.

IACRHR. Rejection to the request of an advisory opinion presented by the Inter-American Commission of Human Rights. Order of May 29 $9^{\text {th }}, 2018$.

IACRHR. Rejection to the request of an advisory opinion submitted by Costa Rica. Order of May 10 $0^{\text {th }}, 2005$.

IACRHR. Rejection to the request of an advisory opinion submitted by the Inter-American Commission of Human Rights. Order of June $24^{\text {th }}, 2005$.

IACRHR. Rejection to the request of an advisory opinion submitted by the Inter-American Commission of Human Rights. Order of January $27^{\text {th }}, 2009$.

IACRHR. Rejection to the request of an advisory opinion submitted by the Secretary General of the Organization of American States. Order of June, 23 $3^{\text {rd }}, 2016$.

IACRHR. Reports of the Inter-American Commission on Human Rights (Art. 51 American Convention on Human Rights). Advisory Opinion OC-15/97 of November 14, 1997. Series A, n. 15.

IACRHR. Request for an advisory opinion presented by the Inter-American Commission on Human Rights. Order of the Inter-American Court of Human Rights of June 24, 2005.

IACRHR. Rights and guarantees of children in the context of migration and/or in need of international protection. Advisory Opinion OC 21/14 of August 19 $9^{\text {th }}, 2014$. Series A, n. 21.

IACRHR. Rules of procedure. Approved by the Court during its LXXXV Regular Period of Sessions, held from November 16 to 28, 2009. Available at: http://www. corteidh.or.cr/sitios/reglamento/nov_2009_ing.pdf. Access on: 10 jun. 2019.

IACRHR. The institution of asylum, and its recognition as a human right under the Inter-American System of Protection (interpretation and scope of Articles 5, 22(7) and 22(8) in relation to Article 1(1) of the American Convention on Human Rights). Advisory Opinion OC 25/18 of May 30 th, 2018. Series A, n. 25.

ICJ. Accordance with international law of the unilateral declaration of independence in respect of Kosovo. Advisory Opinion of $22^{\text {nd }}$ July 2010. Available at: http://www.icj-cij.org/ files/caserelated/141/141-20100722-ADV-01-00-EN. pdf. Access on: 08 apr. 2020. 
ICJ. International Court of Justice: handbook. The Hague: International Court of Justice, 2013.

ICJ. Legal consequences of the construction of a wall in the occupied palestinian territory. Advisory Opinion of $9^{\text {th }}$ July 2004. Available at: https://www.icj-cij.org/files/caserelated/131/131-20040709-ADV-01-00-EN.pdf. Access on: 08 apr. 2020.

ICJ. Legal consequences of the separation of the Chagos Archipelago from Mauritius in 1965. Advisory Opinion of $25^{\text {th }}$ February of 2019. Available at: https://www.icj-cij.org/ files / case-related/169/169-20190225-01-00-EN.pdf. Access on: 08 apr. 2020.

MAC-GREGOR, Eduardo Ferrer. What do we mean when we talk about judicial dialogue? Reflections of a judge of the Inter-American Court of Human Rights. Harvard Human Rights Journal, v. 30, 2017.

NOWAK, Bruna. Entre diálogos e monólogos: um estudo sobre as referências da Corte Internacional de Justiça à jurisprudência das cortes regionais de direitos humanos. 209 f. Dissertação (Mestrado em Direito) - Faculdade de Direito, Universidade Federal do Paraná, Curitiba, 2018.

OAS. Inter-american democratic charter. Lima, 2001. Available at: https://www.oas.org/charter/docs/resolution1_en_p4.htm. Access on: 10 jun. 2019.

PAÚL, Álvaro. Rechazo de solicitudes de opinión consultiva por parte de la Corte Interamericana de Derechos Humanos. Revista Chilena de Derecho y Ciencia Politica, p. 119-131, ene./mayo 2017.

ROA, Jorge Ernesto. La función consultiva de la Corte Interamericana de Derechos Humanos. Temas de Derecho Público n. 94. Instituto de Estudios Constitucionales Carlos Restrepo Piedrahita. Bogotá: Universidad Externado de Colombia, 2015.

RUNAVOT, Marie-Clotilde. La compétence consultative des juridictions internationales: reflet des vicissitudes de la fonction judiciaire internationale. Paris: L.G.D.J., 2010.

SLAUGHTER, Anne-Marie. A typology of transjudicial communication. University of Richmond Law Review, v. 29, p. 99-137, 1994.

SOLEY, Ximena; STEININGER, Silvia. Parting ways or lashing back? Withdrawal, backlash and the InterAmerican Court of Human Rights. Max Planck Research Paper Series n. 2018-01, p. 1-26, 2018.
TZANAKOPOULOS, Antonios. Judicial dialogue in multilevel governance: the impact of the Solange argument. In: FAUCHALD, Ole Kristian; NOLLKAEMPER, André (ed.). The practice of international and national courts and the (de-)fragmentation on international law. Oxford, Portland: Hart Publishing, 2012. 
Para publicar na Revista de Direito Internacional, acesse o endereço eletrônico www.rdi.uniceub.br ou www.brazilianjournal.org.

Observe as normas de publicação, para facilitar e agilizar o trabalho de edição. 